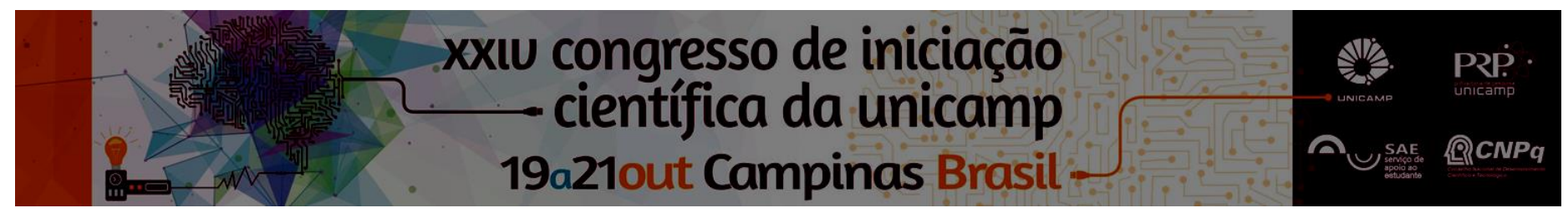

\title{
The scientific production about Youth and Adult education in Brazil: research groups
}

\section{Bárbara F. Estevanato*, Joyce Wassem.}

\begin{abstract}
This paper is a study on research groups (RG) that are focused in Youth and Adult Education (YAE). For the data collection, the directory of the Research Groups was taken, by the use of descriptors related to YAE. The qualitative and quantitative analysis of the 158 groups found relating directly to the subject allows to be inferred that educational policies for the YAE have contributed to the interest in this area as a space for discussion of the right to education and social inclusion.
\end{abstract}

\section{Key words:}

Youth and Adult Education, Research Groups, Educational Policies.

\section{Introduction}

The production of scientific knowledge in Brazil has increased significantly in recent decades. This increase has been attributed to the growth of the Postgraduate Programs (PP) and to the Research Groups (RG) (Robl; Meneghel, 2003).

This study sought to develop a study on research groups about Youth and Adult Education, seeking to contribute to the debate about the characteristics of the production of knowledge about this field in the Brazilian scenario. Although this topic appears repeatedly on the agenda of national debates on education in Brazil, there is still a relatively small amount of research in the area that, as highlighted by Miguel Arroyo (2003), has established itself very intensively with its specificity, and with its own difficulties and shortcomings that need to be overcome.

\section{Results and Discussion}

This research has a qualitative character, but it also makes use of quantitative data in regard to the mapping of research groups, such as the amount of existing research groups on the subject, year of creation, geographic and institutional distribution, and others. The basis for the data collection were the groups and lines of research related to this issue certificated in the Directory of Research Groups in Brazil's National Scientific and Technological Development Council (CNPq), through parameterized query in this directory using YAE related descriptors.

Based on the descriptors used, the results show the record of 1250 research groups. From the analysis of the groups, it was selected 158 that are directly related to the theme, being specific about the YAE or presenting any line of research related to the topic. The used descriptors and records were: "Youth and adult" (139 RG); "Young and Adult People" (6 RG); "Adult Literacy" (2 RG); "Technical Education" (2 RG); "Professional Education" (1 RG); "Education in the Field" (2 RG); "Rural Education" (2 RG); "Social Inclusion" (4 RG). Other descriptors were used, but the same groups listed in the above descriptors were identified. It was observed that the groups were predominantly created in recent years in the period between 2001- 2011 (61.7\%) and after 2012, there have already been created 39 RG
$(24.7 \%)$. The groups are mostly registered in the educational area $(93 \%)$, but they also appear in mathematics $(1.9 \%)$, chemistry $(1.3 \%)$ and $0.6 \%$ in ecology, economics, physics, linguistic, languages and sociology. They are mainly allocated in the Northeast region (36.1\%), followed by the Southeast (31.6\%), and South (13.9\%) of Brazil.

\section{Conclusions}

In general, the YAE related research groups are concerned in their studies with teaching practice and social issues. Regarding the educational practices, they focus on teaching methodology, such as: learning materials, activities, curriculum, pedagogical training of teachers who work or will work with the YAE. I.e. related to teaching and learning. With regard to social issues, the groups emphasize YAE as a space of discussion about the right to education, social inclusion and focused on the job training.

The data, finally, allows inferring that educational policies especially directed to the YAE, in recent years, especially after the 1988 Brazilian Federal Constitution, have contributed to the creation and concern in this research area, although this interest is still concentrated in certain regions of the country and clustered in the educational area.

\section{Acknowledgement}

To the Student Support Service - Serviço de Apoio ao Estudante (SAE) of UNICAMP, for the concession of the Social Assistance Scholarship - Bolsa Auxílio Social (BAS) to the scientific project that supports this research.

\footnotetext{
${ }^{1}$ Robl, F; Meneghel, S. M. Produção Acadêmica em Grupos de Pesquisa em Educação - o perfil dos GPs do Sistema ACAFE/SC. In: ALMEIDA, H. C. T.; et al. (Org.). Desafios da educação neste século: pesquisa e formação de professores. Cruz Alta: UNICRUZ, v. 2, 2003, p. 262 - 271.

${ }^{2}$ Arroyo M. Uma escola para jovens e adultos. Conferência - Reflexão sobre a Educação de Jovens e Adultos na perspectiva da proposta de Reorganização e Reorientação curricular, SP, 2003.

${ }^{3}$ BRASIL. Constituição. Constituição da República Federativa do Brasil. Brasília, DF: Senado Federal: Centro Gráfico, 1988.
} 